\title{
US urged to keep labs open to foreigners
}

Washington. A new report from the US National Academy of Engineering has strongly recommended that the United States should keep its doors open to foreign participation in US research and development (R\&D), both public and private.

"In the absence of clear threats to national security, Congress should avoid legislating restrictions on foreign participation in privately funded US R\&D," says the report, which was prepared by a committee headed by Alan Schriesheim, director of the Department of Energy's Argonne National Laboratory in Illinois, and released last week. "Congress should strike reciprocity requirements from existing laws governing federal R\&D spending. and exclude them from future R\&D legislation."

Panel members and outside observers acknowledge that Congress is unlikely to rush to amend existing laws. But the committee wanted to send a strong message that restrictive policies do more harm than good, says Schriesheim. "I hope the report will at a minimum prevent legislation that would close doors."

The committee began work on its report nearly three years ago, when the issue of US 'competitiveness' was more politically charged than it is at present. At the time, anecdotal stories in the media suggested that US companies were being bought up or outmanoeuvred by foreign competitors.

Legislation enacted by Congress in the early 1990 s reflected this anxiety by building in reciprocity agreements to governmentfunded $R \& D$ programmes. This meant that foreign companies that wanted to participate in a Co-operative Research and Development Agreement (CRADA) with the Department of Energy, or in the Commerce Department's Advanced Technology Program (ATP), had first to show that their home governments provided US companies with similar access to $R \& D$ programmes.

Meanwhile, foreign investment in privately financed US R\&D has been growing. The share of total domestic R\&D spending by US affiliates of foreign-owned companies rose from 9.3 per cent in 1982 to 15.5 per cent in 1993, with the pharmaceutical and industrial chemical sectors recording the heaviest foreign investment. The US government has less influence in this area, except where national security is concerned. But the committee argues that this growth, as well as the proliferation of transnational corporate alliances, are, on balance, "positive trends".

The report's enthusiasm for open-door policies partly reflects a change in the political climate, says Schriesheim. The United
States is no longer seen as lagging behind foreign competitors. Global economics and the creation of multinational ventures are more firmly entrenched than ever, and even individual states are eagerly courting foreign investment. As the political atmosphere shifted, panel members who initially had advocated more restrictive stances softened. "The sentiment became more laissez-faire," says Schriesheim.

In fact, the academy report has appeared after the argument has largely ended. No new restrictive legislation has been proposed recently in Congress, and discussion of programmes such as ATP have been more concerned with survival, in a Republicancontrolled Congress that is hostile to "industrial policy".

Although the committee says that it is "convinced that the strength of the US basic research system is closely linked to its openness", it claims there is still a need to deal with unfair practices in the conduct of international R\&D. It calls on the government to monitor and report on US access to government-sponsored $\mathrm{R} \& \mathrm{D}$ in other countries, and to use trade agreements and other tools - rather than what Schriesheim calls the "blunt instrument" of restrictive policies - to ensure reciprocal access.

Tony Reichhardt

\section{Australian industry joins scientists' protests at geology cuts}

Sydney. Earth scientists in Australia and the powerful mining industry have joined forces to oppose severe cuts being proposed for the Australian Geological Survey Organisation (AGSO) in the austerity drive promised by the new conservative Coalition government.

The threat to AGSO broadens the sources of anxiety felt in the science community and technology-based industries, as the agency comes under a third ministry that of Primary Industries and Energy - in addition to two that are already placing pressure on scientists, namely Science and Technology, and Education.

Internal documents reveal that the government is planning 'savings' that would be achieved by slashing AGSO's annual budget by 30 per cent over the next year, from A $\$ 55.5$ million (US\$43 million) to A $\$ 39$ million. This would mean sacking 130 staff -25 per cent of the total - and axing entire survey and research programmes.

Chris Powell, head of geology and geophysics at the University of Western Australia, and president of the Australian Geoscience Council, a federation that represents 7,000 members of nine professional societies, described the proposals as "shortsighted and a bloody disaster".

Programmes or projects marked for severe shrinkage or termination include climate change, the Cooperative Research Centres for Antarctic and Southern Ocean, and for Mineral Exploration Technologies, Antarctic geology, coastal zone studies, national geoscience information system, geohazards, palaeomagnetism and timescales.

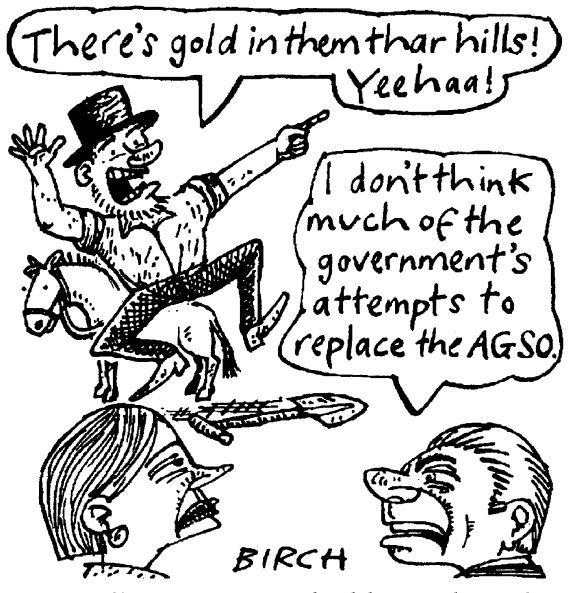

Powell says most valuable work undertaken by the 50 -year-old AGSO, previously known as the Bureau of Mineral Resources (BMR), has been pre-competitive research on mineral and petroleum deposits needed to open up Australia's vast mining potential.

One proposal would be either to terminate the work by the research vessel Rig Seis- mic, or to operate it commercially in competition with private contractors - a prospect that concerns the petroleum industry, which argues that it has already paid for the vehicle once through taxes, as well as scientists, who need unrestricted open access to publicly funded surveys.

Rig Seismic is the only vessel sailing from Australian ports carrying out marine surveys to support exploration and management plans for Australian territorial waters, which have recently been expanded.

"If the cuts go ahead, the government will be squeezing out all the medium-sized companies that cannot afford to do both general surveys and targeted explorations for economic deposits," Powell claims. "The old BMR was responsible, almost singlehandedly, for opening up the North of Australia and generating enormous revenues."

Staff of AGSO are said to have been "stunned" by the extent of the proposed cuts, which are proportionately three times higher than the 10 per cent target for the whole department within which AGSO operates. AGSO executives are also said to be nervous about the future of a new building worth A $\$ 85$ million. The leading industry body, the Australian Minerals Council, has already called on the government to moderate the cuts.

Peter Pockley 